\title{
INVESTIGATING PRE-SERVICE TEACHERS' CLASSROOM MANAGEMENT PRACTICE IN A BILINGUAL CLASS
}

\author{
Dwiniasih \\ Swadaya Gunung Jati University, West Java, Indonesia \\ dwini6644@gmail.com \\ Farah Sukmawati Wahidah \\ Swadaya Gunung Jati University, West Java, Indonesia \\ farah.sukmawatiwahidah@gmail.com, \\ Susanto \\ ${ }^{3}$ Bandar Lampung University, Lampung, Indonesia \\ susanto@ubl.ac.id
}

\begin{abstract}
For the decades, managing classroom becomes one of the most important topics as the concern to be developed by educational department in improving students' quality. One of them is preparing pre-service teachers by strengthening their teaching skills such as managing classroom. Therefore, this study aims to investigate pre-service teacher's classroom management and its problem faced, where observation checklist is used by other participants in reviewing forty respondents' teaching performance. Meanwhile in supporting the second purpose; Interview is used to delve more the problem faced by pre-service teacher while managing classroom. The results reveal that the skill which is still not optimal related to the creation and maintenance of optimal learning conditions is the skill that shows response attitude because of nervous and tend to focus to the certain group or students considered comfortable. Meanwhile, skills related to the control of optimal learning conditions that is still not done optimally by the participants, namely finding and overcoming behavior that poses problems with the way of exile caused by frightened by pre-service teachers against increasingly poor or rebellious student responses. However, referring to overall indicator of classroom management skills, pre-service teacher could be categorized as having done a grade managing skills well.
\end{abstract}

Keywords: Pre-service teachers, Classroom Management, Bilingual Class

\section{A. INTRODUCTION}

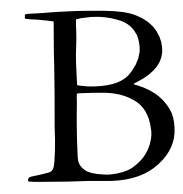

eing a good teacher is not only mastering the learning material delivered to the students, but she should also have a good management, such as in classroom engagement and participation. This is in accordance with Woofolk Hoy and Weinstein (2006) who focused on three factors emerged as good teachers who could organize great relationships with students, apply authority flexibly, and build fun learning. In contrast to the context, classrooms are complex area for learning which involve varied learners with their own characters in a social classroom activity, many rapid, unpredictable, and often public classroom events which have both a related past and a probable future (Wright, 2005 \& Luebbering, 2010), which means that teacher should have expertise in order to do her responsibility in managing classroom. Of course, it is not only how to manage time or space of the classroom since classroom management refers to ways of organizing resources, students, procedures, and routines of a classroom, such as setting-up the room, utilizing 
strategies by the teacher, giving activities to students, monitoring students' behavior, and modifying required instructional practices therefore teaching and learning can proceed in a safe and effective manner (Mason, 2013 \& Jackie Kibler, 2011).

One of the most difficult issues in education recently is how to emphasis the focus from teaching to learning, where the students are the focus in class instead of The teacher, called students center. Again, in doing this thing, teacher is required to be able to solve the context. To do all responsibilities, teacher is required to have skills and knowledge both for learners and herself. Absolutely, it is not coming from her education only, yet her experiences as learner in formal context, or her experiences as a teacher, life experiences or her professional training made her become a professional teacher as it is declared by Wright (2005) that several factors contribute to teachers' professional knowledge, such as 'apprenticeship' knowledge, teaching experience, formal opportunities for further learning and different contexts, and personal life histories. Meanwhile, pre-service teachers have got contribution from personal life histories as a learner and obtained both theory and practice in teaching practicum during the class. Indeed, they dealt with several problems which derived not only from learners, but also from themself. For instance, to adjust an interactive class is not as easy as what theory explained. Learners tended to become too silent, without any response or uncontrolled situation of noises, as well un-expected responses. This situation certainly affected pre-service teacher become stressful, afraid, confused to determine what next to do. As Almog (2002) stated that educators in Israel address the diminish of school discipline problems, signified in students' improper behavior and violation of behavioral norms. Furthermore, they found that time management is as one of eight problems of classroom management confronted by preservice teacher during teaching practicum. It was agreed by several experienced teachers who enroll as supervisor during teaching practicum. They argued that pre-service teachers were not well-prepared in managing time for each teaching session; pre activity, whilst activity and post activity. Mostly, they skipped last session, post activity which involved giving feedback, motivation and concluding the material discussed. It is assumed as not a good teaching process. Meanwhile, an effective classroom management should require further attention in both teacher's preparation and practice. In addition, the important one is early-career teacher attrition (Buchanan et al. 2013).

Referring to what had been generalized, it arouse the writers who are in charged in preparing pre-service teacher before engaging in institution to investigate the problems faced during teaching practicum in a classroom since classroom management includes many elements of preparation and employment, where the most important matter of principals, 
Dwiniasih. Farah, Susanto, Investigating Pre-Service...

teachers, parents, and students perception is maintaining discipline (Romi \& Freund, 1999). Some previous researchers have consistently emphasized the prominence of classroom management knowledge for teachers (Shinn, Walker \& Stoner, 2002). Its result is related to Stough (2006, p.909-910) who claimed that beginning and experienced teachers seems to be unprepared in handling strategies: 'novice and experienced teachers consistently show their training in managing classroom was incompetent or impractical which it needs further planning before teaching implementation. It is consistent to Ben-Peretz, Eilam \& LandlerPardo (2011) that learning classroom management did not give them much effect in their daily teaching. In addition, Stough (2006) claimed that few teacher educations programs in the United States explicitly points out the issue of 'classroom management'. Based on the study conducted by Wesley and vocke (1992) revealed that less than a half of them have a course whose titles appoint to classroom management issues. By all means, this research has an important contribution to build students' professional knowledge becoming a professional teacher who could manage his/her classroom well. Therefore, to perceive how well-prepared the students manage their classroom and reveal all the problems faced by pre-service teacher, the writer conducted this research so that students are ready confronting real challenges, taking care of new things and complexities while managing classroom.

\section{B. REVIEW OF LITERATURE}

There are some aspects which support identifying how well classroom management implemented by the teacher. By following these important components, pre-service teacher could develop individual and classical responsibilities in behaving referred to the rules and activities that are on-going, aware of student needs and provide effective responses to students' behavior during teaching and learning activities taking place. Wardani (2005) suggested two important skills in managing classroom; those are skills related to the creation and maintenance of the optimal learning conditions and skills related to controlling optimal learning conditions. Each component involves skill with its indicator as explained in table 1.1.

Table 1. Components of skills for managing class

\begin{tabular}{cll}
\hline No. & \multicolumn{1}{c}{ Component Skill } & \multicolumn{1}{c}{ Indicator Achievement } \\
\hline $1 . \quad \begin{array}{l}\text { Skills related to the creation and } \\
\text { maintenance of the optimal learning } \\
\text { conditions }\end{array}$ & $\begin{array}{l}\text { Demonstrate responsiveness through looking closely, } \\
\text { approaching, giving statements or reacting to disturbances in } \\
\text { class. } \\
\text { Share attention visually and verbally }\end{array}$ \\
& $\begin{array}{l}\text { Focus the group's attention by preparing students and } \\
\text { demanding student responsibility. } \\
\text { Give clear instructions. } \\
\text { Reprimand wisely, that is clearly and decisively, not in the } \\
\text { form of warnings or babble, and make rules. } \\
\text { Provide reinforcement if necessary. }\end{array}$ \\
\hline
\end{tabular}




$\begin{array}{ll}\text { 2. Skills related to controlling the } & \text { Behavior modification } \\ \text { optimal learning conditions } & \text { Teach the desired new behavior by giving examples and } \\ \text { guidance } & \text { Increase the appearance of good student behavior by } \\ & \text { providing reinforcement } \\ & \text { Reduce the appearance of unfavorable behavior by giving } \\ & \text { punishment. } \\ & \text { Group management / process } \\ & \text { Streamlining tasks by means of working for cooperation and } \\ & \text { establishing work standards and procedures } \\ & \text { Maintaining group activities, by maintaining and restoring } \\ & \text { enthusiasm, handling conflicts that arise, and minimizing } \\ & \text { problems that arise. } \\ & \text { Finding and dealing with the behaviors that cause problems } \\ & \text { by: } \\ & \text { Planned abandonment } \\ \text { Interference with cues } \\ \text { Watch closely } \\ \text { Acknowledge students' negative feelings } \\ \text { Encourage students' awareness to express their feelings } \\ \text { Keep away objects that are annoying } \\ \text { Rearrange learning programs } \\ \text { Relieve tension with humor } \\ \text { Eliminating the causes of interference } \\ \text { Exile }\end{array}$

A good atmosphere of teaching and learning really supports the effectiveness of achieving learning objectives. It is a must for teacher to be able to be a good manager in a teaching and learning process. This means that the teacher should be skilled in creating a conducive learning atmosphere and be able to maintain and restore optimal learning conditions, minimize disruption that may occur during the teaching learning process, so students can focus on it. In implementing classroom management skills, teachers need to pay attention to the component of skills related to the creation and maintenance of optimal learning conditions (such as: the ability of teachers to take initiative and control learning) and repressive skills, namely skills related to teacher responses to disturbances on-going students with the intention that teachers can carry out remedial actions to restore optimal learning conditions.

\section{METHOD}

This research is descriptive study which involved 40 participants who participated in this research activity. It was selected by purposive sampling, where participants were the students who involved in Micro Teaching lectures. In collecting the data, observation checklist and interview adopted from Wardani (2005) are used in this research. The observation as primary research data drew in the participant's review during observing their friends' activities who 
were conducting teaching practicum. Meanwhile, the interview is used to discover the problems faced by the students in managing the class when teaching practice.

This research was conducted through several stages, started by forming a peer-teaching group consisting of three students. Each peer teaching group was observed by other participants, who acted as students at the same time, both junior and senior high school levels. It is as what had been conducted by Wubbels (2011) that the atmosphere of classroom made referred to the perception where social context formed the individual, therefore exercise grants for encouraging group norms and relations for building productive learning circumstances. Through observation checklist distributed through Google form by researchers, participants gave a review of each teaching group performance that focused on the ability of managing classrooms. Meanwhile, to discover the problems faced by pre-service teacher in conducting classroom management, researchers conducted interviews to ten participants after teaching activities in class to strengthen the data.

\section{FINDINGS AND DISCUSSION}

This research has been through several stages of implementation including data collection as explained that the first thing to do is forming a small group of three students to conduct peer teaching simulation. This grouping is done randomly based on the attendance sequence number. This is intended so that there is no grouping of students based on the willingness or proximity factors of individuals. In this stage, the researchers found no significant obstacles. At the previous meeting, the researcher had conveyed that this micro teaching activity was related to teaching practice activities which included the preparation of a teaching implementation plan by each group. Discussions on the results of the lesson plan were conducted during two meetings to see whether the lesson plans that had been prepared had met the criteria as teaching guidelines or not. Revisions were made to groups that did not meet teaching guidelines.

After going through the stage of the equation of perception in the preparation of lesson plans, the next stage is to explain the techniques or strategies during peer-teaching activities. The researchers explained that during this activity, participants, in this case, students who did not carry out teaching activities, would act as observer and also students, both students at the junior and senior high level. Researchers provided flexibility to participants to play a total role as students, not only being a model student, but also being a stubborn or proactive student during class. It is as what had been conducted by Wubbels (2011) that the atmosphere of classroom made referred to the perception where social context formed the individual, 
therefore exercise grants for encouraging of group norms and relations for building productive learning circumstances. This is related to the purpose of the research itself that is how the pre-service teacher's skills in managing classroom which included skills related to the creation and maintenance of optimal learning conditions and skills related to optimal control of learning conditions.

Initially, this teaching simulation was constrained by participants who lacked exploration in the classroom, so that the atmosphere of teaching and learning activities did not look as they were. This is due to the tension or nervousness of each participant, both those who act as students and the teacher itself, which results in the process of data collection being not optimal. But this problem did not last long because after the teaching simulation activity ended, the feedback given by the researcher was able to minimize the nervousness and tension felt by the participants.

The whole teaching simulation activity was conducted thirteen times by several groups and observed by all participants. However, in collecting data, researchers only took eight simulations of the total related to the needs and accuracy of research data. The results of the observations outlined in the observation checklist were then recapitulated in full by the participants. The description of how the performance of prospective teacher student skills in managing classes is explained as in figure 1 and figure 2.

\section{Pre-service teacher's Skill in Managing Classroom When Teaching Practice}

Through the observation checklist distributed to participants, the research focused on two important points in classroom management skills which included skills related to the creation and maintenance of optimal learning conditions and skills related to optimal control of learning conditions. Each of those skills has several indicators as a reference for the success of each skill whether it can be done by pre-service teacher or not as in figure 1. 
Dwiniasih. Farah, Susanto, Investigating Pre-Service...

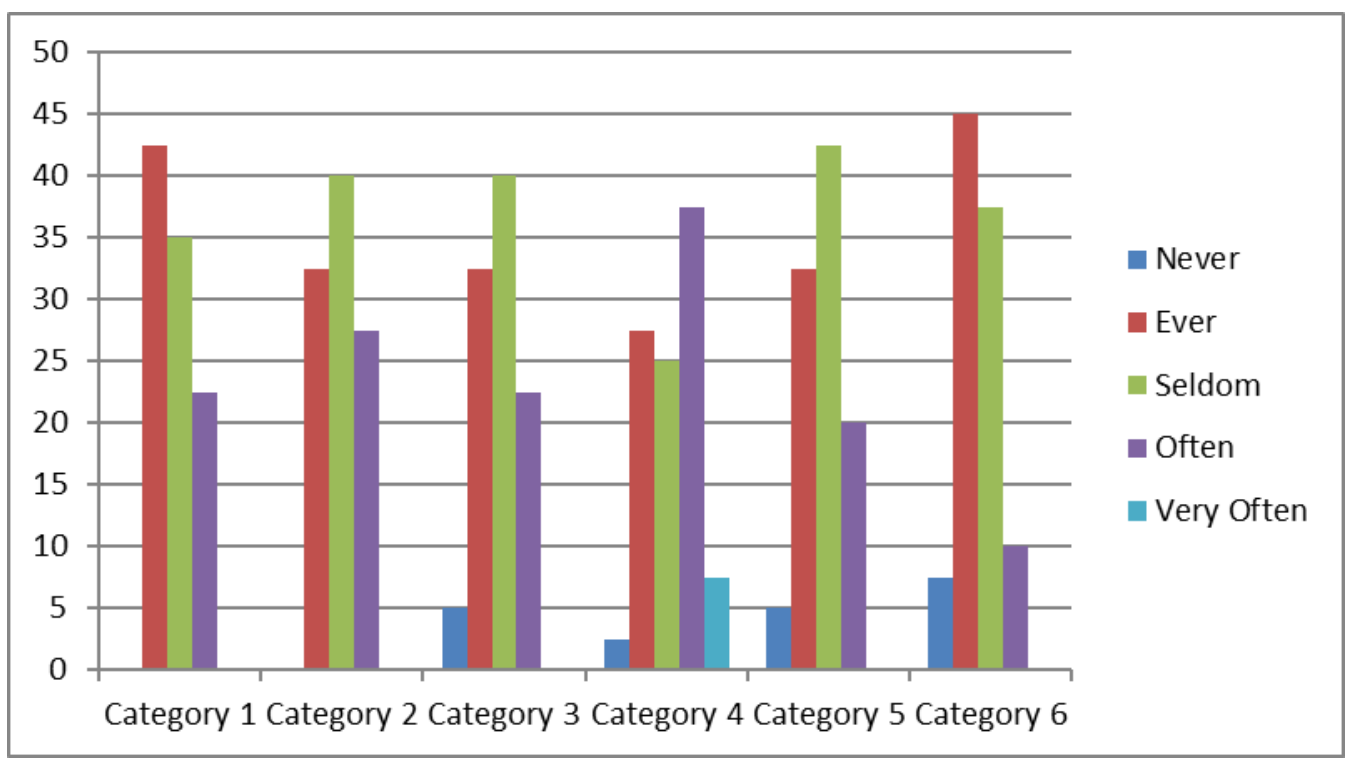

Figure 1. Skills related to the creation and maintenance of optimal learning conditions

The first skill assessed in the skills of creating and maintaining optimal learning conditions in the classroom is the ability of pre-service teachers to show their responsiveness by looking closely, approaching, giving statements or reacting to disturbances in class. Based on the data analysis, $22.5 \%$ often do this skill, $42.5 \%$ ever do this skill, while $35 \%$ participants rarely do this skill. It means that participants are able to manage their classroom by showing their responsiveness well. The second skill is the ability to share attention visually and verbally which shows that participants could do this skill well, even though it was only $32.5 \%$ ever do the skill, and $27.5 \%$ only who often do this skill, while $40 \%$ participants rarely to share attention visually and verbally. As the previous one, the skill of focusing on group attention by preparing and demanding students' responsibility resulted well ability by showing $22.5 \%$ participants often do this skill and 32.5\% ever do this skill, meanwhile $40 \%$ rarely do this skill. In contrast, $5 \%$ participants never did it. It is similar to the skill of providing clear instruction that only $2.5 \%$ who never did this skill since $98 \%$ did providing clear instruction with detail $7.5 \%$ who mostly did it, $37.5 \%$ who often do this skill, $27.5 \%$ who ever conducted this skill, $25 \%$ who rarely to do this skill. It could be assumed that pre-service teachers are able in providing clear instruction to their students. Similar to reprimanding wisely skill that showed 95\% participants could do this skill well, while 5\% were not able to reprimanding wisely which is clearly and decisively done instead of warnings or babble form and making rules. Participants who mostly conducted this skill was about $20 \%$ and $32.5 \%$ was often doing this context, while $42.5 \%$ were rarely to do this. The last skill of creating and maintaining of the optimization learning condition was almost done by $92.5 \%$ by participants. It means that $7.5 \%$ 
could not provide reinforcement if necessary. In detail, 10\% participant mostly doing this skill, $45 \%$ of them ever did it while $37.5 \%$ rarely providing needed reinforcement to their students.

Referring to the description of the results above, it can be concluded that pre-service teacher are able to manage the class well based on skills related to the creation and maintenance of optimal learning conditions. It included skills to show responsive attitudes by: looking closely, approaching, giving statements or reacting to disturbances in class; dividing attention visually and verbally; focus group attention by preparing students and demanding student responsibility; give clear instructions; rebuke wisely, that is clearly and decisively, instead of the form of warnings or babble, and make rules; and provide reinforcement if necessary. Even though it is categorized into well managed, there is still one skill that is still less than optimal performed by the participant, namely the skill of showing responsive attitude. It is contrary to Weinstein, Curran \& Tomlinson-Clarke (2010) that in showing caring, respectful relationship as an essential aspect to students in classrooms is a must to cross social borders, such as setting the tone by greeting students at the door with a smile and a warm, welcoming comment. In some cultures, enacting eye contact is a sign of respect, while in others respect is communicated by keeping up prevented gaze.

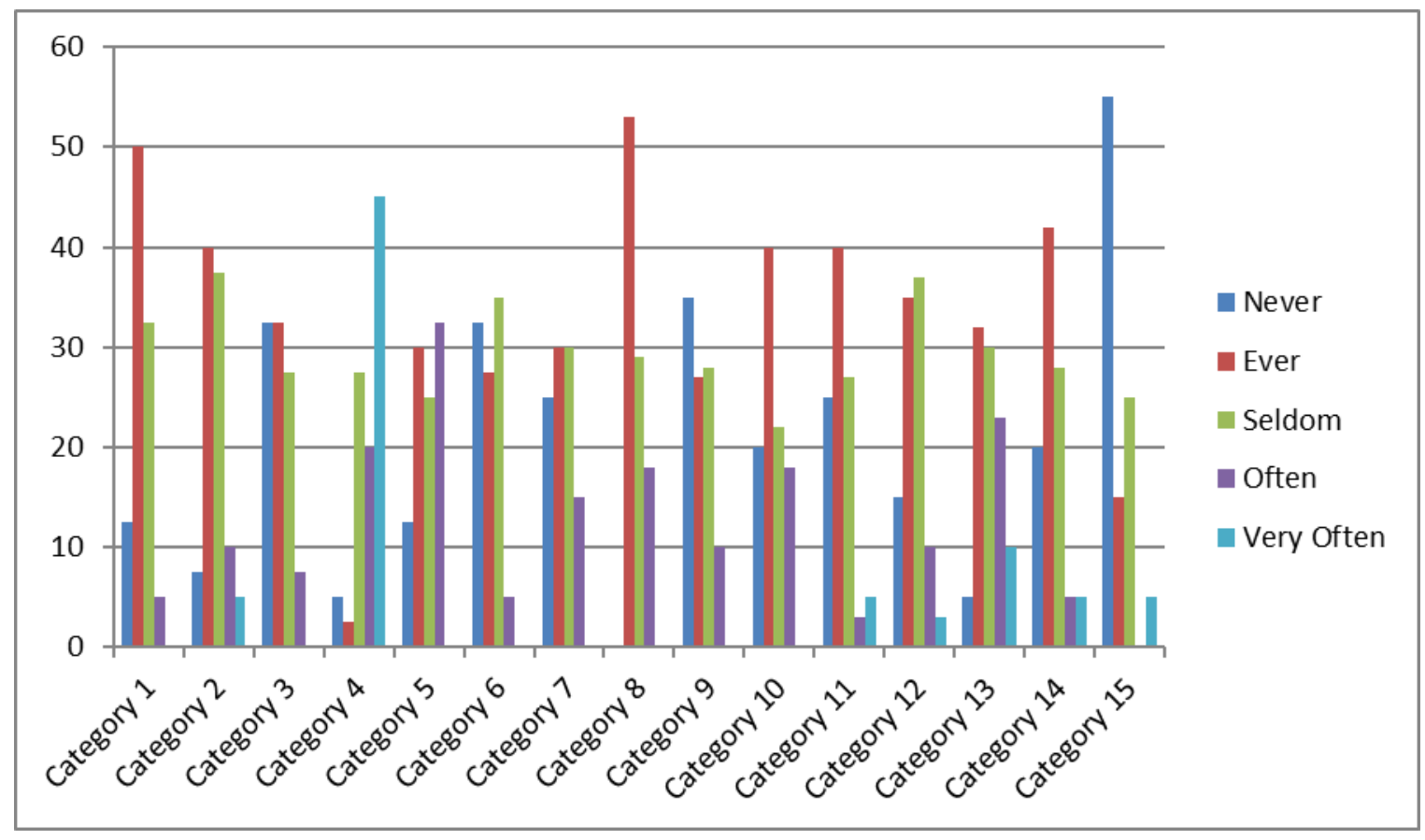

Figure 2. Skills related to optimal control of learning conditions

Next is the discussion of the second components in classroom management as in figure 2, namely skills related to optimal control of learning conditions. These skills included 
modification of behavior, group management / processes, and skills in finding and dealing with behaviors that cause problems. The first indicator in behavior modification is to teach students the desired new behavior by giving examples and guidance. This can be done by $87.5 \%$ pre-service teacher when teaching practicum while the other $12.5 \%$ did not do so by giving examples and guidance. Similarly,-Wubbles (2011) claimed that his study showed the teachers in Hawaii (US) looked a stronger emphasis than in Japan on strategies used, such as setting clear rules, giving detailed instruction, and presenting content in a highly structured fashion). In addition, $92.5 \%$ participants were also able to provide reinforcement well; only $7.5 \%$ did not demonstrate reinforcement as an effort to increase the emergence of good student behavior. It could be described that $5 \%$ mostly providing reinforcement to their students, $10 \%$ often doing this phase, $40 \%$ ever do it in class, and $37.5 \%$ rarely to improve better students' behavior as the reinforcement during learning process. In contrast, the form of controlling the learning conditions by reducing the appearance of unfavorable behavior such as giving punishment is only a half of the total participants who performed this skill. $32.5 \%$ of participants had never given a punishment to reduce the appearance of bad behavior during learning in the classroom. The other one showed $7.5 \%$ often providing punishment, $32.5 \%$ ever did it, whereas $27.5 \%$ rarely doing this treatment. It is a good result since teacher should make an effort to comprehend students' behavior. However, reliance on punishment without going beyond them when necessary would be unsuccessful to manage a sizeable portion of the problem occurred in the classroom (Englehart, 2011). Overall, pre-service teacher could address well the skill of modifying behavior, which means that the purposes of classroom management focus on establishing an orderly environment. Therefore, students could engage in meaningful academic learning and enhance students' social and moral growth (Wubbels, 2011)

Management skills / group processes can also be performed by $95 \%$ of pre-service teacher by streamlining tasks through working towards collaboration and establishing standards and procedures of work. It was very few of them do not make efforts to control classroom conditions in this way which showed $5 \%$ only. 95\% of them who did this skill were $45 \%$ almost doing thses streamlining tasks, $20 \%$ often did it, $2.5 \%$ ever conducted in their class, and $27.5 \%$ were rarely doing this concept in their classroom. In addition to smoothing out tasks, maintaining group management is done by maintaining and restoring morale, handling conflicts that arise, and minimizing problems that arise. This activity was quietly hard to do as shown by $12.5 \%$ participants could not do well this skill. $32.5 \%$ often doing this maintenance group activity, $30 \%$ ever did it whereas $25 \%$ rarely doing this activity. 
The final indicator in optimizing classroom condition maintenance skills is finding and overcoming the behaviors that cause problems in the classroom. It is proposed by doing planned neglect, interfering with cues, watching closely, acknowledging students' negative feelings, encouraging student awareness to express their feelings, keep away objects that are disturbing, rearrange learning programs, eliminate tension with humor, eliminate the causes of disturbances, physical restraint, and isolation. Some of the methods carried out by participants varied greatly, including 32.5\% never did the planned abandonment method. It was conducted by pre-service teacher mostly $5 \%$, while the other $27.5 \%$ ever doing planned neglect and $35 \%$ rarely did this method. It means that most of them are still in the low category in using this method. Still showing 25\%, students did not use interference with cues as a way to find and overcome student behavior that caused problems in the classroom. Whereas $75 \%$ of participants could do this strategy, 15\% mostly used this strategy, 30\% ever did it, and 30\% rarely to use it.

Like other ways before, $35 \%$ of participants did not use ways to overcome student behavior by acknowledging their negative feelings during the learning process. Although $10 \%$ participants did it mostly during teaching practicum, 27\% ever used it, and $28 \%$ rarely acknowledged students negative feeling. Nevertheless, different things are shown by another way, in which all participants do it, i.e. supervise closely, even though the percentage of the implementation is not done every time. They always supervised closely (18\%), 53\% ever did this skill, and $29 \%$ rarely doing this strategy. Similarly, the way to encourage students' awareness to express their feelings as a way to find and overcome student behavior that causes problems in the classroom has done most of the practice as much as $80 \%$, although still on a scale that is not so often, such as $18 \%$ very often used this way, $40 \%$ often did it, and $22 \%$ rarely to use it, whereas $20 \%$ never encouraged students' awareness to express their feeling in class. Other strategies used by pre-service teacher in finding and overcoming the behavior that causes problems was through alienating the disturbing thing from students was about $95 \%$ whereas $5 \%$ never did this way. High percentage rates are still indicated by participants, with a value of $97 \%$ of students being able to find and solve problems by rearranging work programs usually done by teachers when finding a problem that occurs in the classroom to control learning conditions. It is contrary to previous study where only a half of the participants agreed to rearrange teaching strategies by analyzing and ascertaining the knowledge and skills required (Wan, 2015). Likewise, with how to eliminate stressful with humor can be done by the participants well. Only 5\% do not use this method as a form of overcoming student behavior that causes problems in the classroom. Likewise, by eliminating the causes of 
Dwiniasih. Farah, Susanto, Investigating Pre-Service...

disruption as a way to find and overcome the behavior of students who cause problems in the classroom can be done by pre-service teacher. Whereas $20 \%$ of those who did not use this action. The final form of how to find and deal with the behaviors that cause problems in the classroom, it seems that not much is used by participants, only $45 \%$ of the teaching practice.

Based on the discussion above, it can be concluded that, skills related to optimal learning condition control can be performed by all participants. Although there is one point that the participants have not yet carried out optimally, namely finding and overcoming the behaviors that cause problems by way of exile. However, overall, from the indicators of classroom management skills, pre-service teachers' ability can be categorized as having performed class management skills well. As Bear (2015) elaborated that classroom management disruptions would be prevented when a good teacher-student relationship achieved.

\section{Student Problems in Managing Classroom when Teaching Practice}

After knowing the performance of the skills in managing classroom of pre-service teachers as the first objective of this study, the writers now describe the problems faced by students in managing the class when they practice teaching. To find out these problems, the writers used instruments in the form of interviews to obtain accurate and accountable data. The participants in this interview were ten students who had previously participated in Micro Learning classes and acted both as observer and students. Following are the results of interviews obtained and analyzed by the writers which aim to explore the second purpose of this study.

Table 2. Participants' responses on Classroom Management Problem

\begin{tabular}{|c|c|c|}
\hline No. & Questions & Participants' responses \\
\hline 1. & $\begin{array}{l}\text { What is the difficulty to show responsiveness } \\
\text { by: looking closely, approaching, giving } \\
\text { statements or reacting to disturbances in class? }\end{array}$ & $\begin{array}{l}\text { Nervousness which mostly made them silent in front of } \\
\text { the class or looking at certain groups or students who } \\
\text { made them comfortable. }\end{array}$ \\
\hline 2. & $\begin{array}{l}\text { What are the obstacles in dividing attention } \\
\text { visually and verbally? }\end{array}$ & $\begin{array}{l}\text { Shyness, nervous, not concentrating, and can only see } \\
\text { certain groups. }\end{array}$ \\
\hline 3. & $\begin{array}{l}\text { What are the problems that arise when } \\
\text { focusing the group's attention by preparing } \\
\text { students and demanding student } \\
\text { responsibility? }\end{array}$ & $\begin{array}{l}\text { Giving unclear and unspecific instructions; } \\
\text { The commotion of students by several groups that } \\
\text { disturbed others; did not dare to reprimand and got } \\
\text { confused with the choice of words/ reprimands. }\end{array}$ \\
\hline 4. & $\begin{array}{l}\text { What is the form of difficulty when giving } \\
\text { clear instructions? }\end{array}$ & $\begin{array}{l}\text { Nervous, unconfident, and lack of vocabulary \& } \\
\text { grammar mastery make voiceless, fast talking which } \\
\text { affected students' perception in responding the } \\
\text { instruction. }\end{array}$ \\
\hline 5. & les are faced when reprimanding & Afraid of making speech delivery (different expressions \\
\hline
\end{tabular}




\begin{tabular}{l}
$\begin{array}{l}\text { wisely, that is clearly and decisively, not in the of language) therefore affected students feeling } \\
\text { form of warnings or babble, and makes rules? } \\
\text { discomfort and the class is increasingly not conducive, } \\
\text { tends to be passive. Difficult in handling students with } \\
\text { problems (trouble maker). }\end{array}$ \\
$\begin{array}{ll}\text { What are the difficulties when providing } \\
\text { reinforcement as deemed necessary? }\end{array}$ \\
\hline
\end{tabular}

Based on the table 2, pre-service teacher realized it became difficult to show responsiveness either by looking closely, approaching, giving statements or reacting to disturbances in class because of nervousness. They tend to become silent all day long in class, prefer to sit quietly in front of the class, or only look at certain students or groups who were familiar or made them comfortable to talk or discuss. Similarly, when they have to share their attention visually and verbally, nervousness or shyness becomes the main obstacle that interferes with the concentration of teaching. As the previous one, looking at certain students became a solution to interact with the students. Those problems like uncertainties, worries and anxiety faced by participants are also happened to students in handling learner diversity issues (Wan, 2015, p.p 21). Moreover, to get group's attention by preparing students and demanding student responsibility turned into hard to do since they could not give clear and specific instructions. Besides, the commotion of students by several groups that disturbed others were one of the problems faced which discouraged them to reprimand which was caused confusion in words/reprimands choice. Indeed, its problem derives from teachers' emotional experiences which affect their self-perception of classroom situations, such as student misbehavior. Therefore Becker, Keller, Goetz, Frenzel, and Taxer (2015) suggest that it is substantial for teachers to manage their emotions during a lesson. In addition, understanding the arbitrating role of managing emotional between teachers' perceived student misbehavior and emotional exhaustion is important in the classroom (Tsouloupas et al., 2010). Provided that a teacher notices that she or he has low sense of efficacy in dealing with destructive classroom circumstances, the intensity of negative emotions would increase (Chang, 2013; Keller et al., 2014).

Likewise, when giving instructions during the lesson, the voice that should be clearly heard becomes unclear because of nervousness that affected students' confidence. In addition, the lack of mastery in grammar and the limited vocabulary become its own constraints affected miss understanding in delivering speech. Especially, it is when the teacher has to give a clear and firm warning in making rules in the classroom. Thus, modest reprimands and 
tendencies do not care about the problems that arise in the classroom as a form of reinforcement ignored.

Referring to the result discussed, pre-service teachers are able to manage classroom even though there are some components which can not be conducted well. Its problem faced by pre-service teacher during teaching process mostly derives from their own self perception towards misbehavior students. They tend to be unconfident because of their worry, nervousness, and anxiety in handling the awkward and destructive situation. Therefore, it is the duty of the lecturers in educational department who are in charge preparing future teacher to be more aware and caring of what they deal with during practicum in insitution. Indeed, it would be part of further study to involve other aspects which influence students' professional teaching by focusing on classroom management or strengthening its curricula.

\section{E. CONCLUSION}

Classroom management is one of the eight basic teaching skills that are considered as difficult skills for pre-service teacher. This skill consists of two skills that are skills related to the creation and maintenance of optimal learning conditions and skills related to optimal learning condition control. Based on the results of research conducted, it was found that most of the participants had done the classroom management skills quite well. There were some components which were difficult for participants to do, including the skills to show responsiveness due to feeling nervous as the main factors during teaching practice involved skills related to the creation and maintenance of optimal learning conditions. Nevertheless, the skills of finding and overcoming the behaviors that cause problems with exile is a skill related to the optimal control of learning conditions, where pre-service teachers felt worried cause of rebellious students.

For further researcher who are interested in analysing pre-service teacher study, it would be more significant by focusing on classroom management which the participant involved based on students' perception towards pre-service teachers' classroom management skill.

\section{Acknowledgments}

This work supported by the Research Department of Swadaya Gunung Jati University (2019).

\section{REFERENCES}

Almog, T. (2002). What can be done before giving-up. Hed Hachinuch, 76(5), 22-27. (In Hebrew.)

Bear, G. G. (2015). Preventive and classroom-based strategies. In E. T. Emmer \& E. J. Sabornie (Eds.), Handbook of classroom management (2nd ed., pp. 15-39). New York: Routledge. 
Ben-Peretz, M., Eilam, B., \& Landler-Pardo, G. (2011). Teacher education for classroom management in Israel: structures and orientations. Teaching Education, 22(2), 133-150. doi:10.1080/10476210.2011.567842

Becker, E. S., Keller, M. M., Goetz, T., Frenzel, A. C., \& Taxer, J. L. (2015). Antecedents of teachers' emotions in the classroom: an intraindividual approach. Frontiers in Psychology, 6(635), doi:10.3389/fpsyg.2015.00635

Buchanan, J., Prescott, A., Schuck, S., Aubusson, P., Burke, P., \& Louviere, J. (2013). Teacher retention and attrition: Views of early career teachers. Australian Journal of Teacher Education, 38(3), 8.

Chang, M. L. (2013). Toward a theoretical model to understand teacher emotions and teacher burnout in the context of student misbehavior: Appraisal, regulation and coping. Motivation and Emotion, 37(4), 799-817

Englehart, J. M. (2011). Five Half-Truths about Classroom Management. The Clearing House: A Journal of Educational Strategies, Issues and Ideas, 85(2), 70-73. doi:10.1080/00098655.2011.616919

Keller, M. M., Chang, M. L., Becker, E. S., Goetz, T., \& Frenzel, A. C. (2014). Teachers' emotional experiences and exhaustion as predictors of emotional labor in the classroom: An experience sampling study. Frontiers in psychology, 5, 1442.

Kibler J. (2011) Classroom Management. In: Goldstein S., Naglieri J.A. (eds) Encyclopedia of Child Behavior and Development. Springer, Boston, MA

Luebbering B. (2010) Classroom Management. In: Clauss-Ehlers C.S. (eds) Encyclopedia of CrossCultural School Psychology. Springer, Boston, MA

Mason S.A. (2013) Classroom Management. In: Volkmar F.R. (eds) Encyclopedia of Autism Spectrum Disorders. Springer, New York, NY

Romi, S., \& Freund, M. (1999). Teachers', students' and parents' attitudes towards disruptive behavior problems in high school: A case study. Educational Psychology, 19(1), 53-70.

Shinn, M. R., Walker, H. M., \& Stoner, G. E. (2002). Interventions for academic and behavior problems II: Preventive and remedial approaches. National Association of School Psychologists.

Stough, L. M. (2006). The place of classroom management and standards in teacher education. In C. Evertson \& C. Weinstein, (Eds.). Handbook of classroom management: Research, practice, and contemporary issues (pp. 909-923). Mahwah, NJ: Erlbaum. 10.4324/9780203874783.ch34

Tsouloupas, C. N., Carson, R. L., Matthews, R., Grawitch, M. J., \& Barber, L. K. (2010). Exploring the association between teachers' perceived student misbehaviour and emotional exhaustion: The importance of teacher efficacy beliefs and emotion regulation. Educational Psychology, 30(2), 173-189

Wan, S. W.-Y. (2015). Differentiated instruction: Hong Kong prospective teachers' teaching efficacy and beliefs. Teachers and Teaching, 22(2), 148-176. doi:10.1080/13540602.2015.1055435 
Dwiniasih. Farah, Susanto, Investigating Pre-Service...

Wardani, Igak. (2005). Dasar-dasar Komunikasi dan Keterampilan Dasar Mengajar. Pusat Antar Universitas untuk Peningkatan dan Pengembangan Aktivitas Instruksional Direktorat Jenderal Pendidikan Tinggi - Departemen Pendidikan Nasional, Jakarta.

Weinstein, C., Curran, M., \& Tomlinson-Clarke, S. (2003). Culturally Responsive Classroom Management: Awareness Into Action. Theory Into Practice, 42(4), 269-276. doi:10.1207/s15430421tip4204_2.

Wesley, D.A., \& Vocke, D.E. (1992, February). Classroom discipline and teacher education. Paper presented at the annual meeting of the Association of Teacher Educators, Orlando, FL. https://eric.ed.gov/?id=ED341690

Woolfolk Hoy, A., \& Weinstein, C. S. (2006). Student and teacher perspectives on classroom management. In C. M. Evertson \& C. S. Weinstein (Eds.), Handbook of classroom management: Research, practice, and contemporary issues (pp. 181-219). Mahwah, NJ: Lawrence Erlbaum Associates.

Wright T. (2005) Managing Engagement: The Affective Dimension of Classroom Life. In: Classroom Management in Language Education. Research and Practice in Applied Linguistics. Palgrave Macmillan, London

Wubbels, T. (2011). An international perspective on classroom management: what should prospective teachers learn? Teaching Education, 22(2): 113-131. doi:10.1080/10476210.2011.567838 